\title{
Corona en arbeidsrecht: hoe NOW verder met loon en werkplek?!
}

\author{
Prof. mr. A.R. Houweling*
}

\begin{abstract}
1 Inleiding
COVID-19 discrimineert niet. $\mathrm{Zij}$ raakt vrijwel iedereen in de hele wereld. Jong en oud, ongeacht nationaliteit en leeftijd. Ook binnen het juridische domein raakt COVID-19 (in)direct zo'n beetje alle rechtsgebieden. Van commercieel contractenrecht (het openbreken van contracten via onvoorziene omstandigheden) ${ }^{1}$ tot straf(proces)recht (bijvoorbeeld het horen van verdachten via Skype) en van onderwijsrecht (borging van de kwaliteit van onderwijs) tot staats- en bestuursrecht (noodwetgeving). Dat ook het arbeidsrecht niet onberoerd is gebleven, blijkt wel uit het feit dat na afloop van de Tijdelijke Noodmaatregel Overbrugging voor Werkbehoud 1 (NOW 1) naar schatting ruim 2,5 miljoen werknemers via 138.586 werkgevers ruim $€ 6,2$ miljard loonsubsidievoorschot genoten. Dat is omgerekend bijna $€ 10$ miljard totale subsidieaanvraag. ${ }^{2}$ Inmiddels is de NOW verlengd tot 1 oktober en wordt zelfs rekening gehouden met een NOW 3.0. Tellen we hier de Beleidsregel tegemoetkoming ondernemers getroffen sectoren COVID-19 (TOGS), de Tijdelijke overbruggingsregeling zelfstandig ondernemers (TOZO) en de Tijdelijke overbruggingsregeling voor flexibele arbeidskrachten (TOFA) bij op, dan kan met recht worden gesteld dat de arbeidsmarkt door COVID-19 in beweging is. Zo werd in juni een werkloosheidspercentage van $4,3 \%$ vastgesteld ten opzichte van $3,6 \%$ in mei. Tijdens de financiële crisis in 2008 duurde het zeven maanden om dezelfde stijging te bereiken die wij nu in dertig dagen zagen gebeuren. En dan te beseffen dat de echte reorganisaties (en daarmee massaontslagen) nog moeten gaan plaatsvinden. Kortom, de arbeidsmarkt staat voor wat uitdagingen. ${ }^{3}$ En die uitdagingen vertalen zich direct in juridische vraagstukken op het terrein van het arbeidsrecht.
\end{abstract}

In deze bijdrage wil ik bij een tweetal van deze coronagerelateerde vraagstukken stilstaan. En nee, die zien niet op de vraag hoe we het bonusverbod bij toepassing van de NOW kunnen omzeilen of in hoeverre werkgevers eenzijdig arbeidsvoorwaar-

\footnotetext{
Prof. mr. A.R. Houweling is hoogleraar Arbeidsrecht verbonden aan de Erasmus School of Law (ESL), Rotterdam.

1. H.N. Schelhaas \& J.H.M. Spanjaard, Contract en coronacrisis, NJB 2020/14.

2. De NOW keert $80 \%$ aan voorschot uit. Vandaar dat het bedrag 'omgerekend' bijna $€ 10$ miljard bedraagt. Zie Regeling 22 juni 2020, Stcrt. 2020, 34308, p. 12.

3. Zie www.cbs.nl/nl-nl/nieuws/2020/29/aantal-werklozen-in-junigestegen-tot-404-duizend.
}

den kunnen wijzigen en loonoffers kunnen verlangen van hun werknemers. ${ }^{4}$ Hoewel uitermate boeiend, zijn inmiddels de nodige beschouwingen over de NOW en eenzijdige wijziging van arbeidsvoorwaarden gepubliceerd. Deze bijdrage ziet op de thans opkomende prangende arbeidsrechtelijke vragen die voor grote groepen werknemers en werkgevers gelden: 'Heb ik recht op loon?' en 'Heb ik recht op een (thuis)werkplek?' Kortom, deze bijdrage ziet op vragen die actueel zijn nu het bedrijfsleven uit lockdowns het reguliere werk weer oppakt en wordt geconfronteerd met structureel minder werk en dreigende nieuwe lockdowns. Moet de werkgever dan toch het loon blijven doorbetalen bij een tweede of derde golf met of zonder staatssteun? Moet hij het loon doorbetalen als een werknemer naar een code-oranjeland is gegaan en in thuisquarantaine moet verblijven, of als een huisgenoot ziek wordt en de werknemer thuis moet blijven? Moet hij meewerken aan een thuiswerkverzoek van de werknemer? Mag de werkgever van werknemers eisen weer naar het werk te komen als werknemers bang zijn aldaar besmetting op te lopen? Kan een werknemer ook geassocieerd arbeidsongeschikt zijn?

In paragraaf 2 wordt het recht op loon in de verschillende coronasituaties behandeld. Aangetoond wordt dat rechters thans een onjuiste maatstaf aanleggen wat art. 7:628 BW betreft. Betoogd wordt dat naarmate de coronacrisis langer voortduurt het exceptionele karakter ervan afneemt en tot andere uitkomsten zal leiden in de loonrisicoverdeling. In paragraaf 3 staan de keuze en regie over de werkplek centraal. Betoogd wordt dat op basis van de Wet flexibel werken (Wfw) en de recente Victoria-beschikking werknemers een sterker (afdwingbaar) recht hebben voor een alternatieve werkplek. Ik sluit af met een conclusie (par. 4). Hierin geef ik in overweging tot een (wettelijke) herverdeling van risicosferen te komen in geval van 'overmacht' van de werkgever.

4. Zie hierover P.A. Hogewind-Wolters \& S.F.H. Jellinghaus, De korte weg van werktijdverkorting naar NOW: speed over perfection?, TAP 2020/95 (hierna: Hogewind-Wolters \& Jellinghaus 2020a) en P.A. Hogewind-Wolters \& S.F.H. Jellinghaus, NOW 2.0: slotakkoord of opmaat?, TAP 2020/159, en over eenzijdige wijziging P.F. van der Heijden, Staathulp en loonsverlaging, NJB 2020, p. 1811 en N. Zekic, All is fair in love and crisis? Loonoffers en goed werknemerschap, TAP $2016 / 77$. 


\section{Recht op loon ...}

\section{1 ... het juridisch kader}

Als tegenprestatie voor het verrichten van de bedongen arbeid dient de werkgever werknemer loon te betalen. Deze wederkerigheid zou met zich moeten brengen dat als de werknemer geen prestatie verricht, de werkgever evenmin gehouden is te presteren. Op grond van art. 7:628 BW ligt een en ander genuanceerder. Voor een goed begrip van deze loondoorbetalingsverplichting bij niet presteren van de werknemer is het nuttig de ontwikkeling van art. 7:628 BW te schetsen. Daaruit blijkt namelijk dat de huidige formulering van art. 7:628 BW niet strookt met de bedoeling van de wetgever en daarmee tot verkeerde conclusies kan leiden.

\subsubsection{Wet op de arbeidsovereenkomst 1907}

De wetgever formuleerde in 1907 de hoofdregel dat geen loon is verschuldigd indien de bedongen arbeid niet wordt verricht (art. 1638b (oud) BW). Deze hoofdregel werd niettemin doorbroken in vier in de wet genoemde gevallen, te vinden in art. 1638 c en $1638 d$ (oud) BW. Ingevolge art. 1638d (oud) BW behield de 'arbeider' recht op het naar tijdruimte overeengekomen loon 'indien hij bereid was den bedongen arbeid te verrichten, doch de werkgever daarvan geen gebruik heeft gemaakt, hetzij door eigen schuld of zelfs ten gevolge van een hem persoonlijk betreffende verhindering'. Uit de memorie van toelichting volgde dat bij het begrip 'persoonlijk betreffende verhindering' onder andere wordt gedacht aan een dienstbode of bediende die geen arbeid heeft kunnen verrichten omdat zijn 'meester' ziek of op reis was, of aan een werknemer die niet heeft kunnen werken omdat de ondernemer het bedrijf waar de werknemer normaliter wordt tewerkgesteld, had gestaakt, terwijl de dienstbetrekking nog niet was geëindigd. ${ }^{5}$ Het werd volgens de wetgever billijk gevonden dat de werknemer in deze omstandigheden aanspraak kon blijven maken op doorbetaling van het overeengekomen loon. Tijdens de parlementaire behandeling bleek dat het begrip 'persoonlijk betreffende verhindering' tegenover het begrip 'overmacht' diende te worden geplaatst. ${ }^{6}$ In geval van overmacht, een begrip dat nogal ruim werd uitgelegd, ${ }^{7}$ zou de werkgever namelijk niet verplicht zijn tot doorbetaling van het loon, omdat niet kon worden gesproken van een 'persoonlijk betreffende verhindering'. De volgende gebeurtenissen werden onder meer als overmacht aangemerkt: onwerkbaar weer, materiaaltekort ten gevolge van een werkstaking, werkstaking, brand, aardbeving en andere natuurrampen.

Tijdens de parlementaire behandeling van art. 1638d (oud) BW in 1906 is de vraag aan de orde gesteld of een deling van het risico tussen werkgever en werknemer soms niet juister zou zijn. Door een drietal Kamerleden werd een amendement ingediend dat de strekking had werknemers aanspraak op 50\%

\footnotetext{
5. A.E. Bles, De Wet op de arbeidsovereenkomst, Den Haag: Belinfante 1908, deel III, p. 2-3 (hierna: Bles III 1908).

6. Bles III 1908, p. 11.

7. J.M. van Slooten, Arbeid en loon, Deventer: Kluwer 1999, p. 182.
}

van het overeengekomen loon toe te kennen ingeval de arbeid niet zou kunnen worden verricht ten gevolge van overmacht: 'De arbeider heeft aanspraak op het halve loon, indien hij bereid was den bedongen arbeid te verrichten, doch de werkgever daarvan door overmacht geen gebruik heeft gemaakt.' ${ }^{\text {' }}$

De indieners vonden het niet billijk dat de werknemer het gehele loon zou ontberen wanneer bijvoorbeeld ten gevolge van slecht weer niet zou kunnen worden gewerkt. In hun ogen zou een fiftyfiftyverdeling tussen werkgever en werknemer veel rechtvaardiger zijn. Hierbij werd door Ruys de Beerenbrouck gewezen op een reeds bestaande praktijk in Duitsland en Nederland. Voor de extra loonlasten die het gevolg zouden zijn van de verplichting om het halve loon bij overmacht te betalen, zou de werkgever een verzekering kunnen afsluiten, waardoor in de praktijk ten minste $70 \%$ van het uit te keren loon zou kunnen worden gedekt. Ook de werkgevers zelf zouden bij het verzekeren van de lonen zijn gebaat, zo betoogden de indieners van het amendement, nu op deze wijze goedgeschoold personeel bij stilstand van het bedrijf behouden zou blijven.?

In de Kamer kreeg het amendement evenwel forse kritiek. De bezwaren die werden aangevoerd, kunnen als volgt worden samengevat. In de eerste plaats zou het amendement leiden tot een onwenselijke afwijking van art. 1281 (oud) BW. Dit wetsartikel hield in dat de schuldenaar die door overmacht werd verhinderd aan zijn verplichtingen te voldoen, bevrijd was van de verplichting tot nakoming. Als tweede bezwaar werd aangevoerd dat de inhoud van het amendement onvoorspelbare financiële gevolgen zou hebben voor de verschillende bedrijfstakken. Zo zouden bijvoorbeeld seizoenarbeiders reeds een hoger loon ontvangen ter compensatie voor de tijd dat niet kon worden gewerkt. Ook werd erop gewezen dat een algemene rechtsovertuiging van de juistheid van het amendement ontbrak. Minister Van Raalte sloot zich hierbij aan. Anders dan ten aanzien van ziekte (art. 1638c (oud) BW), zo stelde hij, kon niet worden gesproken van een 'hier te lande algemeen bestaande rechtsovertuiging, die zou moeten leiden tot hetgeen de geachte voorstellers willen'. ${ }^{10}$ De commissie van rapporteurs, onder voorzitterschap van Drucker, kwam eveneens tot een negatieve beoordeling van het amendement. $\mathrm{Nu}$ slechts weinig informatie beschikbaar was over de gevolgen van het voorstel, het bovendien een voorstel betrof dat nog nergens bestond, in de literatuur niet was besproken en door de praktijk nog niet was voorbereid, zou het aannemen van het amendement volgens de commissie 'een sprong in het duister' betekenen. Het amendement is uiteindelijk door de Tweede Kamer verworpen. ${ }^{11}$

\footnotetext{
8. Bles III 1908, p. 5.

9. Bles III 1908, p. 6.

10. Bles III 1908, p. 12.

11. Bles III 1908, p. 16.
} 


\subsubsection{Toepassing wettelijke regeling Hoge Raad: van overmacht naar toerekening naar billijkheid}

Hoe heeft de Hoge Raad het begrip 'de werkgever persoonlijk betreffende verhindering' versus het in de parlementaire geschiedenis gebruikte begrip 'overmacht' geïnterpreteerd? Analyseert men de jurisprudentie, dan blijkt dat de Hoge Raad een ontwikkeling in het denken hierover heeft doorgemaakt. In 1925 overwoog de Hoge Raad dat aan de regeling van art. $1638 \mathrm{~d}$ (oud) BW, die als uitzondering op de hoofdregel van art. 1638b (oud) BW moest worden beschouwd, 'geen uitbreidende uitlegging mag worden gegeven'. ${ }^{12}$ Volgens de Hoge Raad was het daarom moeilijk vol te houden dat de voortijdige dood van een kraamvrouw, waardoor de diensten van de kraamverpleegster overbodig werden, als een de werkgever persoonlijk betreffende omstandigheid kon worden gekwalificeerd. Hiermee gaf de Hoge Raad er blijk van een ruim overmachtsbegrip te hanteren. ${ }^{13}$ Veel te ruim, volgens een groot aantal auteurs. Van verschillende zijden werd de Hoge Raad verweten een onjuiste beslissing te hebben genomen. ${ }^{14}$

Een ruime overmachtsopvatting lag ook ten grondslag aan een arrest uit $1940,{ }^{15}$ dat betrekking had op een matroos die tijdens een tussenstop van het schip SS Breedijk in Havanna ziek werd en verzorging aan wal nodig had. Na beterschap kon de matroos zijn werk niet verrichten, omdat het schip reeds was vertrokken. Had de werknemer niettemin recht op doorbetaling van loon? Nee, aldus de Hoge Raad. De Breedijk had immers volgens schema gereisd en er had zich geen omstandigheid aan de zijde van de rederij voorgedaan waardoor de werknemer niet kon werken. Er was daarom naar het oordeel van de Hoge Raad sprake van overmacht.

In de jaren zeventig raakt de jurisprudentie ten aanzien van art. 1638d (oud) BW in een stroomversnelling. De Hoge Raad wijst dan een aantal arresten over de vraag of een werkwillige werknemer recht heeft op doorbetaling van loon als hij ten gevolge van een staking zijn werkzaamheden niet kan verrichten (de zogenoemde stakingsarresten). ${ }^{16}$ Nieuw in deze arresten is de wijze waarop de Hoge Raad toepassing heeft gegeven aan art. $1638 \mathrm{~b}$ en $1838 \mathrm{~d}$ (oud) BW, door deze artikelen niet langer op zichzelf, maar in onderling verband te beschouwen. De Hoge Raad sprak namelijk niet langer van een hoofdregel (art. 1638b (oud) BW) en een uitzonderingsregel (art. 1638d

12. HR 23 januari 1925, ECLI:NL:HR:1925:246, NJ 1925, p. 381 (Wilmink/Takke).

13. Van Slooten 1999, p. 185.

14. W.A. Zondag, Werktijdverkorting. Over plaats en functie van een arbeidsmarktinstrument in het arbeidsrecht (diss. Rotterdam), Deventer: Gouda Quint 2001, p. 97.

15. HR 31 mei 1940, ECLI:NL:HR:1940:83, NJ 1940/1129 (Hotting/De Lijn).

16. HR 10 november 1972, ECLI:NL:HR:1972:AC1656, NJ 1973/60 (Meijer/De Schelde); HR 21 oktober 1973, NJ 1973/142 (Beurtvaart-, Brand- en Zeeverzekering/Van Dijk); HR 7 mei 1976, ECLI:NL:HR: 1976:AB9771, NJ 1977/55 m.nt. GJS (Wielemaker/De Schelde); HR 17 november 1978, ECLI:NL:HR:1978:AC6393, NJ 1979/184 (De Raay/ Stichting Rijn-Metaal); HR 25 januari 1980, ECLI:NL:HR: 1980:AB9769, NJ 1980/282 m.nt. GJS (De Schelde/Wielemaker). (oud) BW), maar over twee artikelen die samen 'het geval beheersen', en vervolgens van een vergelijkenderwijs nagaan in wiens risicosfeer de verhindering het meest zou liggen: ${ }^{17}$

'(...) dat een redelijke toepassing van de art. 1638b en $1638 \mathrm{~d}$ BW meebrengt dat de arbeider zijn aanspraak op loon behoudt, indien de bedongen arbeid - buiten schuld van beide pp. - niet gebruikt kan worden ten gevolge van een omstandigheid die in de verhouding tussen de pp. meer in de risicosfeer van de werkgever of diens bedrijf ligt dan in die van de arbeider. ${ }^{18}$

In de literatuur wordt aangenomen dat de Hoge Raad met deze rechtspraak art. 1638d (oud) BW als een risicoverdeling naar billijkheid heeft willen kwalificeren. ${ }^{19}$ De vraag of een verhindering voor risico van de werkgever moet komen, zou dan meer het karakter hebben van een 'subjectieve afweging en waardering' dan van een 'objectieve constatering', hetgeen er volgens Van Peijpe op neerkomt dat de rechter beoordeelt of de werkgever naar billijkheid het risico behoort te dragen. ${ }^{20}$ Niet de 'oude' overmachtsleer, maar de redelijkheid zou thans het nieuwe criterium zijn. Deze zogenoemde 'risicosferenleer' is algemeen aanvaard in de arbeidsrechtelijke literatuur en jurisprudentie. ${ }^{21}$

\subsubsection{Wetswijzigingen 1997 en 2015/2020}

Het tot 1 januari 2020 geldende art. 7:628 lid $1 \mathrm{BW}$, inhoudende dat de werknemer recht heeft op het naar tijdruimte vastgestelde loon indien hij de overeengekomen arbeid niet heeft verricht door een oorzaak die in redelijkheid voor rekening van de werkgever behoort te komen, was een codificatie van de in de vorige paragraaf besproken jurisprudentie over art. 1638d (oud) BW. Ingevolge deze rechtspraak, zo is gebleken, behield de werknemer ook dán recht op loon als het verrichten van de arbeid werd verhinderd door omstandigheden die voor de werkgever in beginsel overmacht zouden opleveren, maar die toch voor zijn rekening werden gebracht omdat zij meer in zijn risicosfeer dan in die van de werknemer vielen. Het werd volgens de wetgever niet wenselijk geacht om de in de jurisprudentie waar te nemen ontwikkeling af te snijden. De toelichting vermeldt hierover:

'In art. 628 lid 1 is daarom een redactie gekozen die bedoelt aan deze rechtspraak een duidelijker wettelijke basis te verschaffen dan het vaag geredigeerde art. $1638 \mathrm{~d}$ BW thans biedt. Daarnaast is een taalkundig wat simpeler formulering gekozen dan in de huidige rechtspraak vaak te vinden is. De formulering is bedoeld als een samenvatten-

17. Zie G.J. Scholten in een noot onder HR 10 november 1972, ECLI:NL:HR:1972:AC1656, NJ 1973/60 (Meijer/De Schelde).

18. HR 10 november 1972, ECLI:NL:HR:1972:AC1656, NJ 1973/60 (Meijer/De Schelde).

19. Vgl. Zondag 2001.

20. T. van Peijpe, Risicoverdeling volgens $1638 \mathrm{~d}$ BW en volgens 7.20.3.8 Ontwerp BW, SMA 1974, p. 151-152.

21. Zie uitgebreid A.R. Houweling (red.), Loonstra\&Zondag. Arbeidsrechtelijke themata. Deel I, Den Haag: Boom uitgevers 2020, hoofdstuk 6. 
de uitdrukking waarmee geen materiële wijziging is beoogd. 22

Als gevolg van de Wet werk en zekerheid (Wwz) is art. 7:628 BW opnieuw gewijzigd. ${ }^{23}$ De nieuwe regeling luidt als volgt:

'De werkgever is verplicht het naar tijdruimte vastgestelde loon te voldoen indien de werknemer de overeengekomen arbeid geheel of gedeeltelijk niet heeft verricht, tenzij het geheel of gedeeltelijk niet verrichten van de overeengekomen arbeid in redelijkheid voor rekening van de werknemer behoort te komen.'

Met de wijziging van art. 7:628 BW is tevens art. 7:627 BW komen te vervallen. De wetgever beoogde met deze wijzigingen een omkering van de bewijslast te bewerkstelligen, maar geen materiële wijziging van art. 7:628 BW. Derhalve blijft de '628-jurisprudentie' van voor 1 januari 2020 relevant. ${ }^{24}$ Toch roepen de gewijzigde redactie en het vervallen van art. 7:627 BW de vraag op of niet in meer gevallen dan voor 1 januari 2020 een bepaald risico voor rekening van de werkgever blijft. Waar voordien de vraag werd gesteld of een bepaald voorval niet in redelijkheid voor rekening van de werkgever moest komen, is het vertrekpunt thans immers dat het voorval dat arbeid verhindert voor rekening van de werkgever komt, tenzij het voor rekening van de werknemer moet komen. Het uitgangspunt lijkt zodoende te zijn omgedraaid. De eerste uitspraken gewezen onder het nieuwe regime lijken in het gewijzigde adagium 'geen arbeid, geen loon' in 'geen arbeid, wel loon, tenzij ...' toch een materiële wijziging te lezen. ${ }^{25}$

Uit de wetshistorie volgt dat met art. 7:628 BW een toerekening naar billijkheid van risicosferen is beoogd. De rechtspraak laat zien dat de omstandigheid dat een werknemer is gedetineerd of een aan zijn schuld te wijten kwalificatie verliest, waardoor het werk inhoudsloos wordt (denk aan het verliezen van het rijbewijs van een internationaal vrachtwagenchauffeur), tot uitsluiting van loon leidt. Het niet hebben van genoeg werk is echter typisch een ondernemersrisico en zal niet tot een dergelijke loonuitsluiting leiden. ${ }^{26}$

22. Kamerstukken II 1993/94, 23438, nr. 3, p. 25.

23. Hoewel de wetswijziging aanvankelijk per 1 januari en later 1 oktober 2015 in werking zou treden, is de wijziging pas op 1 januari 2020 geëffectueerd. Dit had als achtergrond een regeling 'onwerkbaar weer' die nog niet gereed was in 2015. Veel mensen denken dat de wijziging van art. 7:628 BW een uitwerking is van de Wet arbeidsmarkt in balans (WAB), die eveneens op 1 januari 2020 in werking trad, maar dat is dus niet zo. Zie over de wetswijzigingen ook E. Wies \& D.R. Stolwijk, Geen arbeid, toch loon: de gevolgen van de wijziging van art. 7:627 en $628 \mathrm{BW}$, TAP 2020/47.

24. Zie expliciet Kamerstukken II 2013/14, 33818, nr. 3, p. 87-88.

25. Uitdrukkelijk Rb. Oost-Brabant (ktr.) 29 mei 2020, ECLI:NL:RBOBR: 2020:2838 en Rb. Noord-Holland (ktr.) 27 juli 2020, ECLI:NL:RBNHO:2020:5863.

26. Zie uitgebreid Houweling 2020, hoofdstuk 6.

\section{2 ... als de werkgever geen werk voorhanden heeft als gevolg van COVID-19}

Maar wat nu als het niet hebben van werk komt door een pandemie, zoals COVID-19? Op grond van de huidige wettekst van art. 7:628 BW zou al snel de redenering kunnen zijn dat de werkgever het loon moet doorbetalen, tenzij het niet verrichten van de arbeid in alle redelijkheid voor rekening en risico van de werknemer moet komen. En omdat toch moeilijk kan worden betoogd dat de COVID-19-pandemie voor rekening van de werknemer komt, moet de werkgever maar loon doorbetalen. Ik twijfel aan de juistheid van deze redenering.

\subsubsection{Beleidsregels ontheffing verbod op werktijdverkorting} 2004

Voor exceptionele gebeurtenissen, zoals een dijkdoorbraak of oorlogsmaatregelen, geldt als uitgangspunt dat dit niet voor rekening van de werkgever komt en derhalve ook geen loon is verschuldigd. Tot en met 17 maart 2020 hadden we een speciaal instrument dat antwoord bood op dit soort exceptionele gebeurtenissen, de zogenoemde 'short-timevergunning', beter bekend als 'werktijdverkorting'. ${ }^{27}$ Op grond van art. 8 van het Buitengewoon Besluit Arbeidsverhoudingen 1945 (BBA 1945) mag de werkgever enkel met toestemming van de minister de arbeidsomvang verminderen. Uit de Beleidsregels ontheffing verbod op werktijdverkorting 2004 volgde dat het moest gaan om een abnormale vermindering ( $20 \%$ of meer) van bedrijfsactiviteiten door buitengewone omstandigheden veroorzaakt. De short-timevergunning werd voor een periode van maximaal 24 weken verleend. ${ }^{28}$ Door deze vermindering van uren makkte de werknemer aanspraak op een WW-uitkering. De werkgever kon deze WW-uitkering in mindering brengen op zijn loonverplichting op grond van art. 7:628 lid 3 BW. Bijgevolg ontving de werknemer onderaan de streep een gelijk loon, maar werd in feite een deel van de WW-aanspraken opgegeten.

Lezen we de toelichting van de Beleidsregel ontheffing verbod op werktijdverkorting 2004, dan worden daar als voorbeelden van 'buitengewone omstandigheden' genoemd:

'In bepaalde omstandigheden kunnen calamiteiten op het niveau van de onderneming, of bijvoorbeeld plaatselijk of regionaal, die tot werkvermindering hebben geleid, wegens hun buitengewone aard niet aan de werkgever worden toegerekend. Voorbeelden hiervan op het niveau van de onderneming zijn calamiteiten als brand, of blikseminslag. Als er sprake is van plaatselijke, regionale of andere calamiteiten, waarvan de effecten zich niet beperken tot een enkele onderneming, wordt telkens afzonderlijk beoordeeld of zij tot het normale ondernemersrisico behoren of niet. Enkele voorbeelden uit het verleden waarbij dat niet

27. De beleidsregel die uitvoering geeft aan de verbodsontheffing is op 17 maart 2020, 18.45 uur ingetrokken. Zie Besluit 2020-0000039117.

28. Zie https://zoek.officielebekendmakingen.nl/stcrt-2004-199-p13SC67058.html. 
werd aangenomen, zijn: het in 1995 ontruimen van de Betuwe wegens hoog water, de vuurwerkramp in Enschede in 2000, de terroristische aanslagen in de Verenigde Staten in 2001, de oorlog in Irak in 2003, dierziekten die als gevolg van overheidsmaatregelen leiden tot geheel of gedeeltelijke stillegging van productie, verwerking en/of vervoer van al dan niet besmette dieren (MKZ- varkensen vogelpest- crises) en (tot dan toe onbekende) virusziekten zoals SARS.'

Met name de verwijzing naar SARS (in 2004) is natuurlijk belangwekkend in het huidige COVID-19-debat. De regelgever acht dat een verminderde bedrijvigheid vanwege (de maatregelen tegen) een dergelijk virus niet tot de normale bedrijfsrisico's behoort en dus tot de short-timevergunning kan leiden.

\subsubsection{Regeling onwerkbaar weer 2020}

Op grond van art. 7:628 lid 9 BW kan bij regeling van de Minister van Sociale Zaken en Werkgelegenheid worden bepaald dat de loondoorbetalingsverplichting geheel of gedeeltelijk niet geldt indien het niet verrichten van de overeengekomen arbeid het gevolg is van bij die regeling te bepalen buitengewone omstandigheden en aan bij die regeling te bepalen voorwaarden wordt voldaan. De zogenoemde 'Regeling onwerkbaar weer ${ }^{29}$ bepaalt vervolgens in art. 5 dat de werkgever is vrijgesteld van de loondoorbetalingsplicht indien het niet verrichten van de overeengekomen arbeid het gevolg is van andere buitengewone omstandigheden dan buitengewone natuurlijke omstandigheden, voor zover althans ten gevolge daarvan een ontheffing is verleend als bedoeld in art. 8 lid 3 BBA 1945, oftewel: een verleende short-timevergunning. Het gevolg is dat de werkgever over de uren dat hij een 'short-timevergunning' heeft ontvangen geen loonverplichting meer heeft. De werknemer komt - mits hij aan de voorwaarden voldoet in aanmerking voor een WW-uitkering. Het verschil met de situatie tot 1 januari 2020 is dat de werkgever in het geheel geen loonverplichting meer heeft over de 'verkortingsperiode'. De werknemer draagt hierdoor de lasten, want krijgt maar gemiddeld $70 \%$ van het maximumdagloon vergoed via het UWV. Stel, de werkgever vraagt $50 \%$ werktijdverkorting aan, dan ontvangt de werknemer $50 \%$ loon van zijn werkgever en (70\% van 50\%) 35\% uitkering van het UWV. Gedurende de periode van werktijdverkorting gaat de werknemer er dus $15 \%$ op achteruit. Verdient de werknemer meer dan het maximumdagloon, dan zal de achteruitgang meer bedragen. Anders dan bij 'onwerkbaar weer' (art. 4) stelt art. 5 Regeling onwerkbaar weer niet het vereiste dat de werknemer daadwerkelijk een WW-uitkering ontvangt. Voldoet de werknemer niet aan de voorwaarden van de WW, dan verliest hij in dit voorbeeld $50 \%$ loonaanspraak. ${ }^{30}$

29. Stcrt. 2019, 70095

30. Bovendien geldt bij werktijdverkorting art. $18 \mathrm{WW}$ niet, waardoor werknemers de 'volle' toets van de WW moeten ondergaan.
Of deze loonconsequentie echt de bedoeling van de wetgever is (geweest), is niet duidelijk. In de parlementaire geschiedenis van de Wwz is regelmatig gewezen op het belang van 'werktijdverkorting' en de wens een 'dergelijke regeling' te behouden. ${ }^{31}$ Deze uitlatingen hebben echter betrekking op de materiële voorwaarden voor het verkrijgen van 'werktijdverkorting'. Over de privaatrechtelijke loonverhouding wordt met geen woord gerept. Ook het feit dat dit loonrisico is opgenomen in de 'Regeling onwerkbaar weer' duidt niet onmiddellijk op een bewuste keuze. Op de website van het UWV werd uitgegaan van een 'loondoorbetaling' met verrekening van WW-uitkering. Ook de website van de rijksoverheid wees in deze richting: 'Uw werknemers blijven bij u in dienst. Meestal merken zij financieel dus weinig van de werktijdverkorting: zij ontvangen gewoon hun loon. ${ }^{32}$ Oftewel, de informatieverstrekking van overheidswege ging uit van de 'oude systematiek'. ${ }^{33}$ De wet en de regeling leiden als gezegd tot een andere uitkomst, te weten: 'geen recht op loon', maar de aanspraak op een WW-uitkering wordt onverlet gelaten.

\subsubsection{Tijdelijke Noodmaatregel Overbrugging voor Werkbehoud I}

De regeling van werktijdverkorting is op 17 maart 2020, 18.45 uur ingetrokken en vervangen door de Tijdelijke Noodmaatregel Overbrugging voor Werkbehoud (NOW 1). ${ }^{34}$ Art. 3 NOW 1 is duidelijk:

'Het doel van deze regeling is om werkgevers tegemoet te komen in de betaling van de loonkosten, indien sprake is van een acute terugval in de omzet met ten minste $20 \%$ gedurende een periode van drie maanden, vanwege een vermindering in bedrijvigheid door buitengewone omstandigheden die in redelijkheid niet tot het normale ondernemersrisico kunnen worden gerekend, zodat zij werknemers in dienst kunnen houden voor de uren die zij werkten voordat sprake was van deze terugval.' (cursivering AH)

Uit deze omschrijving volgt dat indien een werkgever voldoet aan de voorwaarden voor een NOW-subsidie er toch echt wel heel iets extreems aan de hand is, wat niet voor zijn rekening en risico behoort te komen. De conclusie zou dan moeten luiden dat voor het aandeel omzetverlies dat een werkgever lijdt, hij geen loon is verschuldigd aan de werknemer op grond van de risicosferenleer van art. 7:628 lid $1 \mathrm{BW}$.

Daarover merkt de regelgever in de toelichting bij NOW 1 (p. 20) evenwel iets anders op:

31. Zie G.C. Boot, A.R. Houweling \& M.J.M.T. Keulaerds, Parlementaire geschiedenis Wet werk en zekerheid, Den Haag: Boom Juridische uitgevers 2015 , p. 249

32. Zie www.rijksoverheid.nl/onderwerpen/ww-uitkering/vraag-en-ant woord/aanvragen-werktijdverkorting-en-ww-uitkering-personeel (geraadpleegd op 14 maart 2020).

33. Zie www.uwv.nl/werkgevers/tijdelijk-minder-werk/detail/werktijdver korting/wat-betekent-werktijdverkorting-voor-mijn-werknemers (geraadpleegd op 14 maart 2020).

34. Hogewind-Wolters \& Jellinghaus 2020a. 


\begin{abstract}
'Werknemers in dienst van de werkgever met een vaste arbeidsomvang hebben wettelijk recht op loon zolang het dienstverband voortduurt. Dit geldt ook als zij (deels) niet werken, tenzij het (deels) niet werken voor rekening van de werknemer moet komen (artikel 7:628, eerste lid, BW). De buitengewone omstandigheden waar de NOW op ziet, zijn omstandigheden die niet voor rekening van de werknemer komen. Dat betekent dat werknemers die een arbeidsovereenkomst hebben met de werkgever, recht hebben op doorbetaling van hun loon voor de volledige vaste arbeidsomvang zolang de arbeidsovereenkomst voortduurt, ook als zij niet kunnen werken.'
\end{abstract}

Met Van Slooten vraag ik mij af of dit (a) juist is en (b) van betekenis is. ${ }^{35}$ De uitlating van de minister is onjuist, omdat wanneer we de parlementaire geschiedenis van art. 7:628 BW bestuderen, duidelijk blijkt dat geen inhoudelijke wijziging van lid 1 is beoogd. Bestaande rechtspraak zou onverminderd van toepassing blijven. Kortom, toerekening naar billijkheid. De minister lijkt in deze toelichting de gewijzigde wettekst van 1 januari 2020 als uitgangspunt te nemen en enkel de toets aan te leggen of de buitengewone omstandigheden voor rekening van de werknemer moeten komen. Daarmee wordt een onjuiste maatstaf aangelegd. De uitlating van de minister is voor toepassing van art. 7:628 $\mathrm{BW}$ van geen of weinig betekenis, omdat een enkele opmerking van een minister bij een toelichting van een subsidieregeling (NOW) de uitleg van een door de Tweede en Eerste Kamer uitvoerig besproken wetswijziging niet gemakkelijk kan en mag overrulen. Daarmee zou een eenzijdig genomen besluit van een minister de toepassing van een wet in formele zin substantieel kunnen wijzigen en beïnvloeden.

Iets anders is natuurlijk de vraag of bij de toepassing van lid 1 betrokken kan en mag worden dat een werkgever een NOWsubsidie geniet. En natuurlijk kan dat. Als een werkgever 60\% loonsubsidie ontvangt, dan zal het niet verrichten van de werkzaamheden minder snel tot loonuitsluiting leiden: toerekening naar billijkheid pakt dan in het voordeel van de werknemer uit. Dus de uitkomst is wellicht gelijk, maar de weg ernaartoe anders. Is dit een semantische discussie? Nee, want de NOW-regelingen houden een keer op en dan is opeens de vraag 'voor wiens risicosfeer komt COVID-19?' actueel. Uit de wetssystematiek vloeit voort dat bij acute terugval van werk of zelfs gehele sluiting van bedrijven en sectoren (denk aan niet-vitale contactberoepen die een verbod tot uitoefening van werk opgelegd kregen) als gevolg van een pandemie, de werkgever niet langer gehouden is het overeenkomstige deel van het loon te voldoen. De vaste rechtspraak van de Hoge Raad inzake risicosferen blijft ook vanaf 1 januari 2020 geldend recht. Werknemer zal voor het deel dat hij loonaanspraak verliest, aanspraak moeten maken op de WW. Compenserende maatregelen van de overheid, zoals de NOW, brengen gewicht in de schaal van de risicoverdeling. Keren we terug naar 1906,

35. Zie ook J.M. van Slooten, Rapport commissie-Borstlap daagt het ondernemingsrecht uit, Ondernemingsrecht 2020/29. dan is een voorstel voor een 50-50-verdeling lang zo gek nog niet in absolute overmachtssituaties als hier aan de orde. Overigens ebt het overmachtsargument natuurlijk weg naarmate de tijd voortduurt. Inmiddels kunnen en moeten werkgevers hun bedrijf aanpassen aan de nieuwe werkelijkheid en kunnen ze niet blijven schermen met art. 7:628 BW. Dat is deels ook waar NOW 2 voor is bedoeld (met loonsubsidie overgaan naar de nieuwe realiteit).

\subsubsection{Rechtspraak 2020: COVID-19 en loondoorbetaling}

Hoe gaat tot op heden de rechtspraak om met 'loonrisicoverdelingen' en COVID-19? De eerste en meest genuanceerde uitspraak is die van de kantonrechter Amsterdam. Een Turkse broodjeszaak in het centrum van Amsterdam en voornamelijk gericht op toeristen zag zijn omzet in één keer wegvallen. Aan zijn werknemers berichtte de werkgever dat $50 \%$ van het loon werd opgeschort (voor onbepaalde tijd). De kantonrechter overwoog:

'Aannemelijk is dat bij Dam [werkgever; AH] door de buitengewone omstandigheden waarin zij nu verkeert, een onvoorziene, bedrijfseconomische noodsituatie aanwezig is. Dam heeft een zwaarwichtig belang dat in beginsel meebrengt dat van de medewerkers van Dam gevraagd kan worden om - in overleg - bepaalde arbeidsrechtelijke aanspraken op te schorten of zelfs helemaal prijs te geven. ${ }^{36}$

Uiteindelijk oordeelt de rechter dat 'eenzijdig en zonder overleg voor onbepaalde tijd 50\% loon opschorting naar maatstaven van redelijkheid en billijkheid niet van werknemer kon worden gevergd'. Hoewel de rechter geen uitdrukkelijk standpunt in het 628 -debat inneemt, ${ }^{37}$ blijkt uit de overwegingen wel dat risicodeling in exceptionele gebeurtenissen tot de mogelijkheden behoort. Die benadering komt mij juist voor, alsook het feit dat de omstandigheid dat werkgever voor $60 \%$ een loonsubsidie ontving, een omstandigheid is die in deze risicoverdeling gewicht toekomt.

Een dag later oordeelde de kantonrechter Breda stellig(er) dat het oude adagium 'geen arbeid, geen loon' niet meer gold sinds 1 januari 2020 en op grond van het gewijzigde adagium 'geen arbeid, wel loon' de werknemer recht op loon behield. In casu ging het om een valkenier die seizoenswerk verrichtte in een valkenierspark. Vanwege de coronacrisis is het park gesloten geweest. Toch oordeelde de kantonrechter dat de financiële problemen als gevolg van de coronacrisis geen omstandigheid zijn die de werknemer kan worden tegengeworpen..$^{38}$ Dragend

36. Rb. Amsterdam (ktr.) 28 mei 2020, ECLI:NL:RBAMS:2020:2734, r.o. 11 .

37. Omdat de rechter het aspect van 'overleg' betrekt in het toetsingskader, lijkt de rechter een Stoof/Mammoet-achtige toets aan te willen leggen. Tegelijkertijd klinken ook art. 6:248/258 BW door in de overwegingen, met zelfs een vleugje 'art. 7:613 BW' met de verwijzing naar 'zwaarwichtig belang'. Zie hierover ook de annotatie van J.M. van Slooten in JAR $2020 / 156$.

38. Zie in min of meer gelijke zin Rb. Limburg (ktr.) 22 juni 2020, ECLI:NL:RBLIM:2020:4436. 
voor dit oordeel was in ieder geval dat uit de rechtspraak zou kunnen worden afgeleid dat veel omstandigheden in feite tot de risicosfeer van de werkgever worden gerekend, dus ook deze. ${ }^{39}$ Heel overtuigend is deze motivering niet. Sterker, er zijn voldoende argumenten die voor een andere uitkomst pleiten. Zeker in een situatie waarin een werkgever door overheidsmaatregelen wordt gedwongen zijn deuren te sluiten, is het moeilijk vol te houden dat hier sprake is van een 'risico dat voor rekening van de werkgever moet komen'.

\section{3 ... als de werknemer niet durft te werken, vanwege besmettingsrisico}

Wat heeft te gelden als de werkgever wel werk heeft, maar de werknemer niet op het werk durft te komen omdat hij bang is besmet te raken? En maakt het daarbij uit dat die angst voortkomt uit het feit dat werknemer zelf tot een risicogroep behoort of een kind heeft met een auto-immuunziekte? En wat als de collega met wie hij op een kamer zit, samenleeft met iemand die op de corona-afdeling van een ic werkt? Natuurlijk kan de werkgever schermen met het opvolgen van alle RIVMmaatregelen en arboregels. Kan hij daarmee 100\% besmettingsvrij garanderen? Nee, natuurlijk niet. En zo kunnen we nog wel wat variaties verzinnen. De vraag is welk toetsingskader geldt hier? Het bijzondere aan deze casus is dat de werknemer 'besmettingsrisico' vreest. Hij is (nog) niet ziek. Hij vreest ziek te worden. En dat doet in zekere zin denken aan situatieve arbeidsongeschiktheid. In 2008 heeft de Hoge Raad zich in het arrest Mak/SGBO over situatieve arbeidsongeschiktheid uitgelaten. ${ }^{40}$ De Hoge Raad overwoog toen als volgt:

'In een geval als het onderhavige, waarin sprake is van een verstoorde arbeidsverhouding, kan zich de situatie voordoen dat de werknemer zich op grond van (dreigende) psychische of lichamelijke klachten niet in staat acht tot het verrichten van zijn werkzaamheden, hoewel ten aanzien van de arbeidsgeschiktheid geen medische beperkingen van psychische of fysieke aard kunnen worden vastgesteld, zodat van arbeidsongeschiktheid ten gevolge van ziekte in de zin van art. 7:629 BW geen sprake is. Dit geval wordt wel aangeduid als "situatieve arbeidsongeschiktheid" en de vraag doet zich voor in hoeverre in zo'n geval gezegd kan worden dat de werknemer zijn werkzaamheden niet heeft verricht door een oorzaak die in redelijkheid voor rekening van de werkgever behoort te komen, als bedoeld in art. 7:628 lid 1 BW.'

We zien in deze omschrijving dat de Hoge Raad situatieve arbeidsongeschiktheid reserveert voor niet medisch gerelateerde arbeidsongeschiktheid, op grond waarvan art. 7:629 BW niet aan de orde is. Onder welke voorwaarden kan nu worden gezegd dat een ontstane situatieve arbeidsongeschiktheid in

39. Rb. Oost-Brabant (ktr.) 29 mei 2020, ECLI:NL:RBOBR:2020:2838, r.o. 4.15 .

40. HR 27 juni 2008, ECLI:NL:HR:2008:BC7669, JAR 2008/188 (Mak/ SGBO). redelijkheid voor rekening van de werkgever dient te komen? Op die vraag geeft de Hoge Raad geen rechtstreeks antwoord, maar hij benoemt wel de regels van stelplicht en bewijslast. Een zware stelplicht en bewijslast wordt bij de werknemer neergelegd. ${ }^{41}$ De Hoge Raad stelt zich namelijk op het standpunt dat het de werknemer is die feiten en omstandigheden moet stellen en zo nodig aannemelijk moet maken die tot het oordeel kunnen leiden dat in die periode de arbeidsomstandigheden, door een oorzaak die in redelijkheid voor rekening van de werkgever behoort te komen, voor hem zodanig waren dat, met het oog op de (dreiging van) psychische of lichamelijke klachten, van hem redelijkerwijs niet kon worden gevergd dat hij zijn werkzaamheden zou verrichten. Uit de parlementaire geschiedenis van de $W_{w z}$ volgt dat deze rechtsregel ook geldt onder de huidige redactie van art. 7:628 BW, waarin nu juist de bewijslastomkering tot een andere uitkomst zou leiden. ${ }^{42}$

Een dergelijk toetsingskader kan ik mij ook voorstellen bij werknemers die uit vrees voor besmetting niet naar het werk komen. Als de werkgever netjes alle arbo- en overheidsrichtlijnen heeft gevolgd, dan mag van de werknemer worden verwacht dat hij stelt en bewijst waarom toch niet gevergd kan worden dat hij naar het werk komt. Daarbij is voorstelbaar dat een werknemer een deel van het werk thuis kan blijven doen en voor het andere deel niet werkt en bijgevolg geen loon ontvangt.

\section{4 ... als werknemer naar code oranje/rood reist of een zieke huisgenoot heeft}

Over de vraag hoe het zit met vakantieverlof en het intrekken van reeds vastgestelde vakantie door een werknemer of juist het verplichten met vakantie te gaan door de werkgever is aan het begin van de coronacrisis veel geschreven. ${ }^{43}$ Directe aanleiding was vooral het massaal intrekken van meivakanties door werknemers. Inmiddels doet zich een andere vraag voor, te weten hoe om te gaan met een werknemer die op vakantie gaat naar een code-oranjegebied, zodat hij versterkte risico's loopt op ziekte en/of een quarantaineperiode? Of wat als een werknemer op vakantie gaat naar een land waarvan ten tijde van vertrek voorzien is dat gedurende het vakantieverlof het reisadvies van geel in oranje kan veranderen? Op grond van de RIVM-richtlijnen die door de rijksoverheid zijn overgenomen, dient een werknemer bij terugkeer uit een code-oranjeland tien dagen in thuisquarantaine te verblijven. ${ }^{44}$ Passen we hier de regels van art. 7:628 BW op toe, dan lijkt dit een evidente situatie van 'voor rekening en risico van de werknemer'. De tien dagen thuisquarantaine komen dan voor rekening van de werknemer. Als de werknemer 'vanuit huis' kan werken, dan is

41. Zie hierover R.A.A. Duk, De Hoge Raad en rechtsvinding in het arbeidsrecht (diss. Rotterdam), Den Haag: Boom Juridische uitgevers 2013, p. $47-48$.

42. Zie over deze vraag ook Wies \& Stolwijk 2020.

43. J.R. Vos, Vakantie in tijden van corona, TAP 2020/131.

44. Zie www.rijksoverheid.nl/onderwerpen/coronavirus-covid-19/neder landse-maatregelen-tegen-het-coronavirus/vakantie-in-eigen-land-enreizen-naar-het-buitenland. 
het anders omdat hij de bedongen arbeid kan blijven verrichten.

Een enkele keer wordt bij deze vraag wel de vergelijking gemaakt met 'opzettelijk ziek' worden in de zin van art. 7:629 lid 3 BW. Gewezen wordt dan op het arrest Zutekouw/Van Ort, waarin de Hoge Raad herhaalde dat 'opzet' ex art. 7:629 lid 3 BW betekent dat het handelen van de werknemer willens en wetens is gedaan met als doel ziek te worden. ${ }^{45}$ Iemand die naar Portugal op vakantie gaat, heeft niet de wens ziek te worden. Toch gaat deze analogie met Zutekouw/Van Ort niet op. Om te beginnen is art. 7:629 BW niet van toepassing omdat de werknemer (nog) niet ziek is. Daarnaast is de causaliteit in dit geval gegeven doordat de werknemer op vakantie gaat naar een code-oranjeland en het 'dwingende advies' van de rijksoverheid is dat men dan tien dagen in thuisquarantaine moet blijven.

En wat nu als een huisgenoot ziekteverschijnselen als koorts en droge hoest vertoont, dan luidt de RIVM-richtlijn 'blijf thuis'. Moet in zo'n geval, waarin de werknemer ook geen arbeid vanuit zijn thuissituatie kan verrichten, de werkgever het loon blijven doorbetalen? Volgens de kantonrechter Maastricht luidt het antwoord bevestigend. ${ }^{46}$ Volgens de rechter geldt,

'[i]ndien een werknemer in contact is geweest met een persoon die mogelijk besmet is met het coronavirus of een zieke huisgenoot heeft en van overheidswege in quarantaine moet en niet thuis kan werken omdat dit in zijn/haar beroep onmogelijk is, is dat een omstandigheid die niet in de risicosfeer van werknemer ligt. De werkgever is in dat geval verplicht het loon door te betalen.'

Ook hier lijkt de gewijzigde wettekst van art. 7:628 lid $1 \mathrm{BW}$ in het voordeel van de werknemer uit te pakken. Een goede argumentatie waarom een typisch persoonlijk risico als 'ziekte' of 'contact met een zieke werknemer' tot loondoorbetaling van de werkgever moet leiden, is niet onmiddellijk gegeven. Temeer niet als het ook nog eens door een verplichting van overheidswege komt dat de werknemer thuis moet blijven. ${ }^{47}$

In de Maastrichtse zaak speelde de vraag of in dit geval niet gewoon sprake was van 'ziekte' in de zin van art. 7:629 BW. Onder het regime van art. 7:629 BW is het mogelijk twee wachtdagen voor rekening van de werknemer te laten vallen. Bovendien hoeft een werkgever maar $70 \%$ van het maximumdagloon te betalen, in plaats van $100 \%$ van het contractuele

45. HR 14 maart 2008, ECLI:NL:HR:2008:BC6699, JAR 2008/110. 46. Rb. Limburg (ktr.) 24 juni 2020, ECLI:NL:RBLIM:2020:4465.

47. Art. 4:1 van de Wet arbeid en zorg (WAZO) geeft de werknemer in bijzondere omstandigheden recht op 'doorbetaald verlof indien sprake is van het niet kunnen verrichten van de werkzaamheden voor een korte, naar billijkheid te berekenen tijd, vanwege (lid 1 onder c) een door wet of overheid, zonder geldelijke vergoeding, opgelegde verplichting, waarvan de vervulling niet in zijn vrije tijd kon plaatsvinden. De overheidsmaatregel van thuisquarantaine valt hier niet onder. Gedacht moet worden aan 'aangifte van een kind' tijdens kantooruren. loon op grond van art. 7:628 BW (als je niet vindt dat de werknemer helemaal geen recht op loon heeft). Ten slotte heeft de werkgever meer 'tools' om de werknemer te prikkelen iets te doen. Bijvoorbeeld de verplichting contact op te nemen met de bedrijfsarts. De kantonrechter oordeelt - niet verrassend - dat nu werknemer zelf niet ziek is, er geen sprake is van 'arbeidsongeschiktheid wegens ziekte'. Dit oordeel lijkt mij juist. Toch is het ook weer niet heel ondenkbaar om het regime van art. 7:629 BW van toepassing te verklaren in dit soort gevallen. Wellicht dat hier de figuur van 'associatie' uitkomst kan bieden. We kennen deze figuur met name in het gelijkebehandelingsrecht, de zogenoemde associatieve discriminatie. ${ }^{48}$ Een persoon kan zich dan associëren met het rechtsobject van bepaalde regels en zo onder een regime vallen dat op voorhand niet voor hem is geschreven. Als een huisgenoot ziekteverschijnselen vertoont waardoor de vanuit de overheid opgelegde regels dwingen tot thuisblijven, kan dan niet worden betoogd dat in feite sprake is van 'associatieve arbeidsongeschiktheid wegens ziekte'?

Waarom zou je dit willen? Misschien zijn het regime van art. 7:629 BW en de rol van de bedrijfsarts een procedure die wat meer waarborgen kent voor beide partijen als het aankomt op het betwisten van de 'ziekte'. Een werknemer die een appje stuurt met 'mijn huisgenoot heeft koorts, ik blijf thuis', moet je maar geloven als werkgever. Het is nogal ingewikkeld om van de werknemer te verlangen dat hij een getekende verklaring van de huisarts van zijn huisgenoot moet overleggen om te bewijzen dat de huisgenoot 'koortsig' is. Dit soort verwerking van bijzondere persoonsgegevens is in de werkgeverwerknemerrelatie al ingewikkeld, laat staan dat het om gezondheidsgegevens van een derde (de huisgenoot) gaat. De bedrijfsarts kan hierin mogelijk een meer onafhankelijke partij vormen, die in vertrouwelijkheid de zaak kan peilen. Op grond van art. 7:629a BW kan bij een eventuele loonvordering van de werknemer een deskundigenoordeel worden verlangd.

Persoonlijk vind ik dat art. 7:628 BW in dit soort gevallen het risico bij de werknemer legt. Het is een omstandigheid die losstaat van het werk, gelijk aan ziekte. Het feit dat een werknemer ziek is en recht behoudt op loon is enkel vanwege de wettelijke grondslag ex art. 7:629 BW. Op grond van art. 7:629 BW zou dit risico voor rekening van de werknemer komen. In veel gevallen zal de werknemer overigens wel 'iets' van nuttig werk voor de werkgever kunnen doen, waardoor geheel verlies van loon niet snel aan de orde zal zijn. In andere gevallen zal het verlies aan loon van korte duur zijn. Wordt de werknemer alsnog ziek, dan verschiet zijn rechtspositie van kleur, van art. 7:628 naar art. 7:629 BW, met als gevolg dat de loonverplichting onverkort geldt.

48. HvJ EG 17 juli 2008, ECLI:EU:C:2008:415. 


\section{Recht op werk}

\section{1 ...thuis}

Wellicht een van de grootste veranderingen en blijvende gevolgen van de coronacrisis is het op grote schaal thuiswerken. Uit diverse onderzoeken blijkt dat een groot deel van de werkers een substantieel deel van de werktijd thuis wil blijven werken. De vraag rijst in hoeverre de werknemer dit kan 'eisen' van zijn werkgever.

\subsubsection{Wet flexibel werken}

Met de Wfw werd voorgesteld het recht van werknemers op aanpassing van de arbeidsduur uit te breiden met de mogelijkheid voor werknemers werkgevers te verzoeken (a) buiten de 'normale' werktijden te werken en/of (b) een deel van het werk buiten de normale plaats, bijvoorbeeld thuis, te verrichten. ${ }^{49}$ De aanleiding voor deze uitbreiding was volgens de indieners gelegen in de omstandigheid dat de toenmalige vormgeving van de arbeidsmarkt - negen-tot-vijfbenadering, inflexibele roostertijden, verplichte kantooraanwezigheid en lange files in de spits - werknemers belemmerde in het toenemende belang van een goede balans tussen arbeid en privé. ${ }^{50}$ Op grond van de Wfw heeft als uitgangspunt te gelden dat het recht op flexibel werken werknemers de mogelijkheid biedt bij de werkgever een verzoek tot wijziging van (a) arbeidsduur, (b) werktijden en (c) arbeidsplaats in te dienen. Van de werkgever wordt verlangd dat hij dit verzoek serieus in overweging neemt en in geval van afwijzing met goede argumenten aangeeft waarom het verzoek niet kan worden ingewilligd. Daarbij geldt zelfs dat de werkgever bij een verzoek ten aanzien van a en $\mathrm{b}$ zwaarwegende bedrijfsbelangen moet hebben voor afwijzing. Deze hoge drempel voor afwijzing geldt echter niet voor een c-verzoek. Met de tweede nota van wijziging is de aanvankelijk eveneens zware toets van 'zwaarwegende bedrijfsbelangen' voor plaatsonafhankelijk werken gewijzigd in een lichter regime, waardoor meer sprake is van een 'right to ask, duty to consider'. De werkgever moet een verzoek voor aanpassing van de werkplaats overwegen. Als hij het verzoek niet inwilligt, zal hij dit met de werknemer moeten overleggen. ${ }^{51}$ Kortom, het recht op thuiswerken is niet 'hard'. Daar komt bij dat de Wfw niet geldt voor werkgevers met minder dan tien werknemers in dienst.

Wel komt de werknemer op grond van art. 7:611 BW het recht toe voorstellen te doen aan de werkgever waar de werkgever onder omstandigheden mee zal moeten instemmen. ${ }^{52}$ De omstandigheid dat in veel sectoren mensen inmiddels drie tot vier maanden zonder problemen thuiswerken, maakt wel dat de 'duty to consider' in het licht van art. 7:611 BW iets meer inhoudt dan enkel een 'overdenking'. De werkgever zal een goed verhaal moeten hebben waarom het thuiswerken opeens niet meer kan. Overigens zijn daarvoor natuurlijk aller-

49. Zie Stb. 2015, 245 en Stb. 2015, 246.

50. Kamerstukken II 2011/12, 32889, nr. 5, p. 1.

51. Kamerstukken II 2014/15, 32889, nr. 17, p. 2.

52. HR 21 februari 2020, ECLI:NL:HR:2020:283. lei goede argumenten te geven. Juniormedewerkers moeten worden ingewerkt. Dat gaat niet digitaal op afstand. En medior-/seniormedewerkers moeten deze junioren opleiden. Of het 'informele contact', dat zich lastig laat 'platformiseren' via Skype, Zoom of MS Teams en een belangrijk onderdeel vormt van de bedrijfscultuur, waarom fysiek contact toch belangrijk is.

\subsubsection{Rechtspraak}

In een zaak die speelde bij de kantonrechter Nijmegen stelde werknemer zich op het standpunt dat mede op grond van de RIVM-richtlijnen zij een recht op thuiswerken kon afdwingen. ${ }^{53}$ De werkgever viel niet onder de Wfw wegens het getalscriterium, zodat een beroep op deze wet niet opging. De kortgedingrechter overweegt:

'Het zeer algemeen geformuleerde overheidsadvies over zoveel mogelijk thuis werken grijpt niet zo ver in op deze specifieke rechtsverhouding dat [eiser] daaruit een "recht op thuis werken" kan putten. Haar standpunt dat dit overheidsadvies de instructiebevoegdheid van VoC Grootkeukens inperkt en/of op grond van redelijkheid en billijkheid zonder meer door een goed werkgever moet worden gevolgd, houdt geen stand.'

Omdat in deze zaak de werkgever voldoende had uiteengezet wat het belang van 'korte lijnen' was om juist in economisch spannende tijden alles draaiende te houden, en bovendien een veilige werkomgeving garandeerde, kon het verzoek van werknemer niet worden gehonoreerd. ${ }^{54}$

Voor toekomstige zaken kan ik mij voorstellen dat inspiratie wordt opgedaan in de (oude) re-integratiejurisprudentie van de Hoge Raad. Onder omstandigheden mag van een werkgever worden gevergd bepaalde bedrijfsprocessen aan te passen, om werknemers optimaal te faciliteren zo veel mogelijk aan het werk te blijven. Er zijn echter grenzen. Een van die grenzen is het overbelasten van andere collega's met bepaald werk. Stel dat een aantal werknemers thuis wenst te werken, met als consequentie dat collega's al het 'zware inpakwerk' moeten doen, en juist de afwisseling van het administratieve en inpakwerk het werk 'uitdagend' houdt en 'mogelijk' maakt. Dan is dat een omstandigheid die de werkgever mag aangrijpen om niet mee te werken aan een thuiswerkverzoek. ${ }^{55}$

\section{2 ... bij de werkgever}

Maar nu een omgekeerd scenario. Want niet alleen werknemers zien de voordelen van thuiswerken, ook veel werkgevers zien besparing van dure vierkante meters kantoorruimte en krimp van leasewagenparken, met bovendien productievere en gelukkigere werknemers. Kan een werkgever de werknemer

53. Rb. Gelderland (ktr.) 16 juni 2020, ECLI:NL:RBGEL:2020:2954.

54. Zie voor een precoronaverzoek tot structureel een dag thuiswerken Rb. Amsterdam 6 november 2018, ECLI:NL:RBAMS:2018:7998.

55. Zie naar analogie HR 26 oktober 2001, ECLI:NL:HR:2001:AB3098, JAR 2001/238. 
verplichten voortaan thuis te werken? Dan wel kan de werkgever voorwaarden stellen aan het verschijnen op het werk (op-en-afschema's, andere kantoorindeling enzovoort)?

Om met het laatste te beginnen, ja, de werkgever heeft op grond van zijn gezagsverhouding ex art. 7:610 BW en instructierecht ex art. 7:660 BW de bevoegdheid instructies te geven ten aanzien van het werk. Looppaden, kantoorindeling en kantoortijden vallen allemaal binnen deze bevoegdheid. Daar komt bij dat de werkgever niet alleen rekening dient te houden met het belang van die ene werknemer, maar ook met de belangen van alle andere werknemers. Hierdoor is de belangenafweging van een werkgever inherent anders dan die van de werknemer. En, zo versta ik de Hoge Raad in zijn Xella-beschikking, ${ }^{56}$ komt de werkgever vanuit deze institutionele benadering op grond van art. 7:611 BW onder omstandigheden een sterker eenzijdig wijzigingsrecht toe dan de werknemer.

Mag de werkgever de werknemer dwingen permanent thuis te werken? In veel gevallen zal de werkplaats zijn benoemd, dan wel op grond van FNV/PontMeyer ${ }^{57}$ een dusdanige gedragslijn zijn dat sprake is van een arbeidsvoorwaarde. Als de werkgever deze arbeidsvoorwaarde wenst te wijzigen, dan zal hij daartoe het geëigende wijzigingsarsenaal moeten toepassen. $\mathrm{Nu}$ is het eenzijdig wijzigen van arbeidsvoorwaarden in Nederland een lastige - zo niet onmogelijke - opgave. Daar komt in dit geval art. 8 EVRM bij. Een werknemer die uit vrije wil thuis wenst te werken om arbeid en privé in balans te brengen, zal niet piepen. Een werknemer die liever niet heeft dat zijn privétijd en werk te veel vermengen, zal grote moeite hebben met deze inbreuk op zijn 'private life' als de werkgever opeens het 'kantoor in de woonkamer' plaatst.

Kortom, 'binnen de vier muren van de werkgever' heeft de werkgever redelijk de vrije hand. Daarbuiten liggen de kaarten snel anders. Dat een werkgever voor de thuiswerkplek verantwoordelijkheden en zorgplichten naar zich toe trekt, is evident. $^{58}$

\section{Conclusie}

COVID-19 heeft een enorme impact op de arbeidsmarkt. Werkgevers worden geconfronteerd met nieuwe vraagstukken, zoals doorbetaling van loon aan werknemers bij 'lockdowns', wijzigingsverzoeken van werknemers wat werkplek betreft en de geassocieerde zieke werknemers. In deze bijdrage heb ik vooral stilgestaan bij de vraag hoe art. 7:628 BW moet worden gelezen en toegepast in deze coronacrisis. De conclusie is dat de wetsgeschiedenis alle ruimte biedt voor maatwerk en als uitgangspunt steun biedt voor het 'overmachtsverweer' van de

\footnotetext{
56. HR 8 november 2019, ECLI:NL:HR:2019:1734.

57. HR 22 juni 2018, ECLI:NL:HR:2018:976.

58. Zie hierover M. ten Broeke \& I. Baijens, Werken vanuit huis: het juridisch kader, ArbeidsRecht 2019/28. Hof Amsterdam 7 september 2006, ECLI:NL:GHAMS:2006:AZ5431. Zie ook A.G.J.J. Jansen, 'Het nieuwe werken': aan het werk in plaats van naar het werk, ArbeidsRecht $2011 / 50$.
}

werkgever. De feitenrechtspraak laat een ander beeld zien en wijst loonvorderingen van werknemers toe. Onder verwijzing naar een amendement van nota bene 1906 herhaal ik een eerder door Zondag ${ }^{59}$ gedaan pleidooi voor een aangepaste risicoverdeling in dit soort buitengewone omstandigheden. In 1906 is voorgesteld in geval van 'overmacht' tot een 50-50-verdeling te komen. Daarmee wordt de 'pijn' tussen partijen gedeeld. In het hedendaagse arbeidsrecht is een 70-30-verdeling niet ongebruikelijk (denk aan loondoorbetaling tijdens ziekte ex art. 7:629 BW en WW-uitkering). Rechters zouden in een voorkomend geval tot een partiële loonaanspraak over kunnen gaan. Beter is een aanpassing van het Besluit onwerkbaar weer (art. 7:628 lid 9 BW) en daarin een uitdrukkelijke risicoverdeling opnemen voor dit soort extreme gevallen.

De (bescheiden) rechtspraak laat een wisselend beeld zien over de waarde van RIVM-richtlijnen. Indien sprake is van een 'zieke huisgenoot', dan wordt de richtlijn 'dwingend' geacht. In geval van 'zo veel mogelijk thuiswerken' leest de rechter aanmerkelijk meer discretionaire ruimte voor werkgevers. Voor het inhouden van loon van werknemers die in thuisquarantaine moeten nadat ze naar een code-oranjeland zijn afgereisd, is nog geen rechtspraak voorhanden, maar ligt uitsluiting van loon voor de hand (tenzij thuisgewerkt kan worden).

Wat betreft wijziging van de werkplek is gewezen op de Wfw in relatie tot het 611-aanpassingsrecht van de werknemer. Betoogd is dat naarmate werknemers langer thuiswerken, de 'duty to consider' van de werkgever steeds meer neigt naar een 'duty to accept'. Omgekeerd zal het voor werkgevers niet gemakkelijk zijn te eisen dat werknemers voortaan allemaal thuis blijven werken. Niet alleen is het Nederlandse eenzijdige wijzigingsrecht daartoe te stringent, ook het recht op 'private life' zonder inmenging van de werkgever weegt hier mee.

\footnotetext{
59. W.A. Zondag, Deeltijd-WW: geliefd en verguisd, TAP 2009, p. 121.
} 